\title{
THE USE OF UNCERTIFIED SEEDS -COMMON BUT DANGEROUS PRACTICE THAT PROMOTES THE SPRED OF XANTHOMONAS CAMPESTRIS PV. VESICATORIA (DOIDGE) DYE
}

\author{
Daniela Mincă $^{1, *}$, Rodi Mitrea ${ }^{1}$ \\ ${ }^{1}$ University of Craiova, Faculty of Horticulture, Craiova, Romania
}

\begin{abstract}
The main sources of primary infection for Xanthomonas spp. species, which cause the disease called bacterial spot of tomato and pepper, are infected seeds, as well as infected seedlings for planting. Bacteria can survive on and inside the seeds for a very long time, from a few months to 10 years, and plants that grow from infected seeds, even if initially are asymptomatic, when favorable conditions for the development of phytopathogens are met, such as heat and humidity, it begins to show symptoms of the disease. For the detection and identification of bacteria Xanthomonas campestris pv. vesicatoria were performed analyses according to the flow diagram of the OEPP working protocol PM 7/110 (1) from 2013. Sample came from a crop set up using seeds from the previous year's crop and was consisted in fruits and leaves of Kapia peppers, Elephant Ears variety (Slonovo Uvo) was taken from a farm in Argeş County, Leordeni village in August 2019. Seeds kept by farmers from contaminated tomato and pepper crops and used as propagation material in the following years increase the danger of the spread of this phytobacteriosis and affects production and fruits quality.
\end{abstract}

Keywords: contaminated seeds, disease, propagation material.

\section{INTRODUCTION}

Xanthomonas spp. bacterium is responsible for the production of the bacterial spot of tomato and pepper. The diseases are made by four bacterial species: Xanthomonas euvesicatoria Jones et.al. (2004), Xanthomonas vesicatoria (e.g. Doidge 1920) Vauterin et.al. (1995), Xanthomonas perforans Jones et.al. (2004) and Xanthomonas gardneri (e.g. Šutic 1957) Jones et.al. (2004) (EFSA PLH Panel, 2014).

In national legislation is listed as a quarantine organism under the name of Xanthomonas campestris pv. vesicatoria (Doidge) Dye in Annex II, Part A, Section II of HG 563/2007, with subsequent amendments and which transposes Directive 2000/29/EC (Official Monitor of Romania, Part I, No. 468 bis/12.VII.2007, Decision for the approval of the methodological norms for applying the Government Ordinance No. 136/2000 regarding the protection measures against the introduction and spread of the quarantine organisms harmful to plants or plant products in Romania) and is monitored by the National Phytosanitary Authority and National Phytosanitary Laboratory is authorized to performed analyses for this quarantine organism.

Acording to EFSA (European Food Safety Authority) the host plants with economic importance are Lycopersicon lycopersicum and Capsicum annuum. 
Current Trends in Natural Sciences

Vol. 9, Issue 17, pp. 31-37, 2020

https://doi.org/10.47068/ctns.2020.v9i17.004

Current Trends in Natural Sciences (on-line)

ISSN: 2284-953X

ISSN-L: 2284-9521
Current Trends in Natural Sciences (CD-Rom)

ISSN: 2284-9521

ISSN-L: 2284-9521

The paper presents a case study from 2019 of a pepper sample found positive on laboratory tests, sample consisted of fruits and leaves of Kapia peppers, Elephant Ear variety (Slonovo Uvo), a variety very well adapted to the climatic conditions from Romania, with large and very sweet fruits (150-300 grams).

The symptoms present on the leaves and the fruits were typical symptoms of bacterial spot of pepper, spots with different shapes, sizes and colors:

- leaves had small, circular, green spots, and many of them were already necrotic and irregular and surrounded by a chlorotic halo;

- fruits had circular, prominent or sunk spots with a rough surface;

- fruit stalks also showed obvious symptoms of the disease (figure 1)

The symptoms present in the study sample are similar to those mentioned by Severin and Iliescu in 2006 and Aielo in 2013.

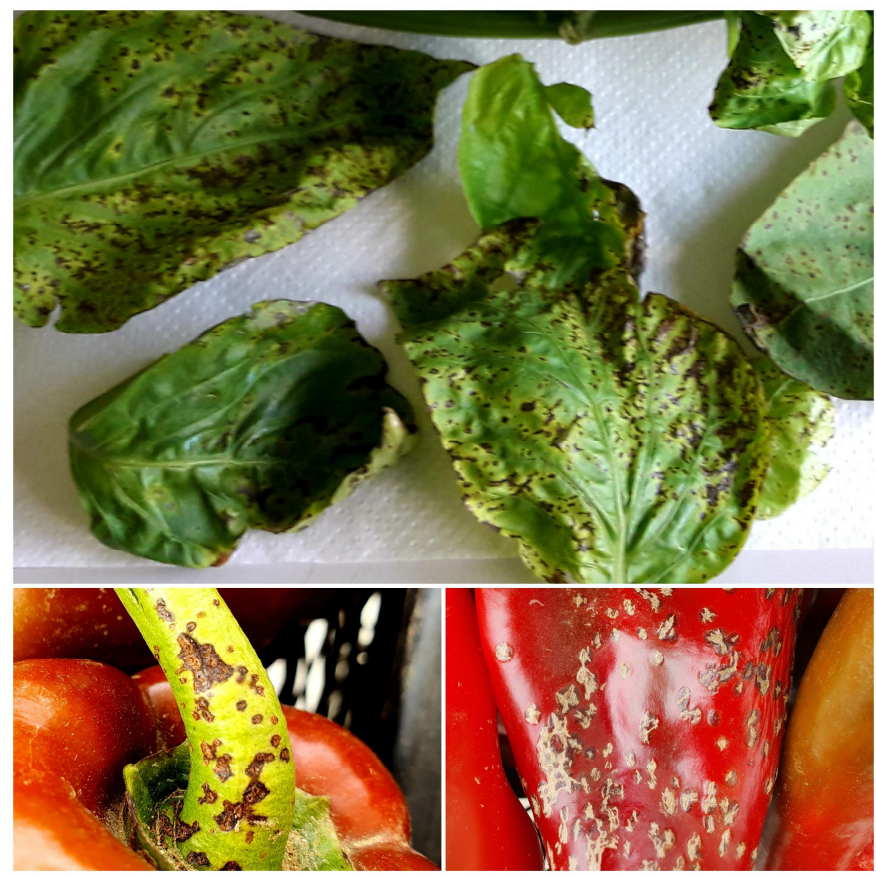

Figure 1. Symptoms on leaves, stalks and fruits

\section{MATERIALS AND METHODS}

The samples analyzed were taken from a farm in Argeş County, Leordeni village in August 2019. The fruits came from a crop set up using seeds from the previous year's crop. According to the farmer, he had been using his own seeds for seedling production for three years and had noticed symptoms, decreased fruit production and quality on the last two years, but he doesn't realized that the contaminated seeds is the problem. He even changed the place of production but the problem persisted.

The methods of analyses performed for the detection and identification of this phytobacterium were in accordance with the European and national legislation.

The analyses were carried out in the bacteriology laboratory of the National Phytosanitary Laboratory which is responsible for performing the analyses for this quarantine pathogen and were followed the provisions of the EPPO protocol PM 7/110 (1), 2013 regarding to detection and 


\section{Current Trends in Natural Sciences}

Vol. 9, Issue 17, pp. 31-37, 2020

https://doi.org/10.47068/ctns.2020.v9i17.004

Current Trends in Natural Sciences (on-line)

ISSN: 2284-953X

Current Trends in Natural Sciences (CD-Rom)

ISSN: 2284-9521

ISSN-L: 2284-9521

ISSN-L: 2284-9521

identification of the Xanthomonas spp. (Xanthomonas euvesicatoria, Xanthomonas vesicatoria, Xanthomonas perforans şi Xanthomonas gardneri) wich cause bacterial spot of tomato and pepper. The analyses methods used in the bacteriology laboratory were: indirect immunofluorescence IFI, isolation on two non-selective culture media (NA-nutrient agar and YPGA - yeast-pepton-glucoseagar), Multiplex PCR test, BIOLOG tests and pathogenicity test on young tomato plants of susceptible cultivars Moneymaker in the greenhouse, according to the flow diagram of the EPPO working protocol PM 7/110 (1), 2013.

\section{RESULTS AND DISCUSSIONS}

Fist method performed for the detection was indirect immunofluorescence IFI, which consists in antibody staining (method RENAR accredited - ASRO - SR EN ISO 17025, 2018). Polyclonal antisera from Loewe-Germany was used for staining, following the requirements of the EPPO diagnostic protocol PM 7/97 (1), 2009 Indirect immunofluorescence test for plant pathogenic bacteria (figure 2).

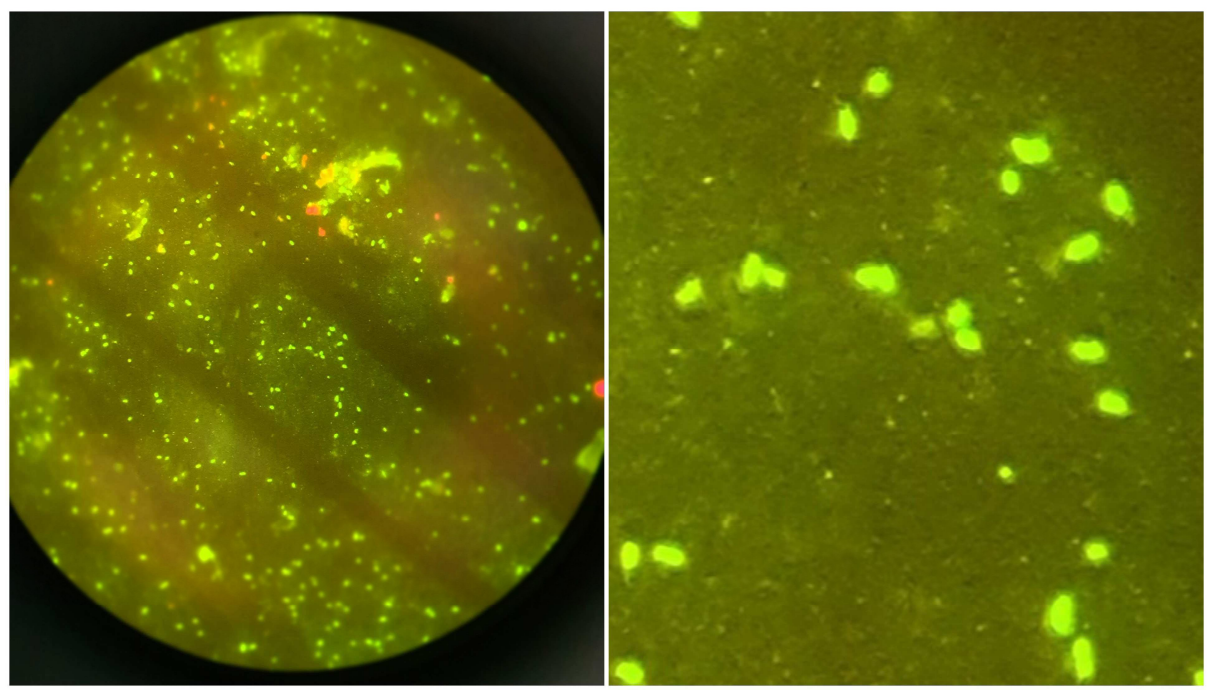

Figure 2. Bacterial cells seen at the epifluorescence microscope

Following a positive test results on IFI screening tests, sample was isolated on two different nonselective culture media: NA - nutrient agar and YPGA - yeast-pepton-glucose-agar.

Bacterial colonies that developed on this non-selective culture media were mucilaginous, round, glossy, prominent and yellow. They showed cultural differences depending on the media where they grow, as follows: on NA the colonies were yellow, round, with the margin bordered, smooth, shining, prominent, convex and have $1 \mathrm{~cm}$ after 4 days of incubation (figure 3), while on YPGA the colonies were bright yellow, wet, mucoid and slightly raised, circular, with entire margin, shining (figure 4).

The development of bacterial colonies on nutrient agar media was similar to that described by Patel since 1950 and the colonies developed on non-selective media, YPGA and NA media were also similar to those described by Severin and Iliescu in 2006. 


\begin{tabular}{lcr}
\hline & $\begin{array}{c}\text { Current Trends in Natural Sciences } \\
\text { Vol. 9, Issue 17, pp. 31-37, 2020 } \\
\end{array}$ & Current Trends in Natural Sciences (CD-Rom) \\
https://doi.org/10.47068/ctns.2020.v9i17.004 & ISSN: 2284-9521 \\
Current Trends in Natural Sciences (on-line) & ISSN-L: 2284-9521 \\
ISSN: 2284-953X & & ISSN-L: 2284-9521 \\
\hline
\end{tabular}

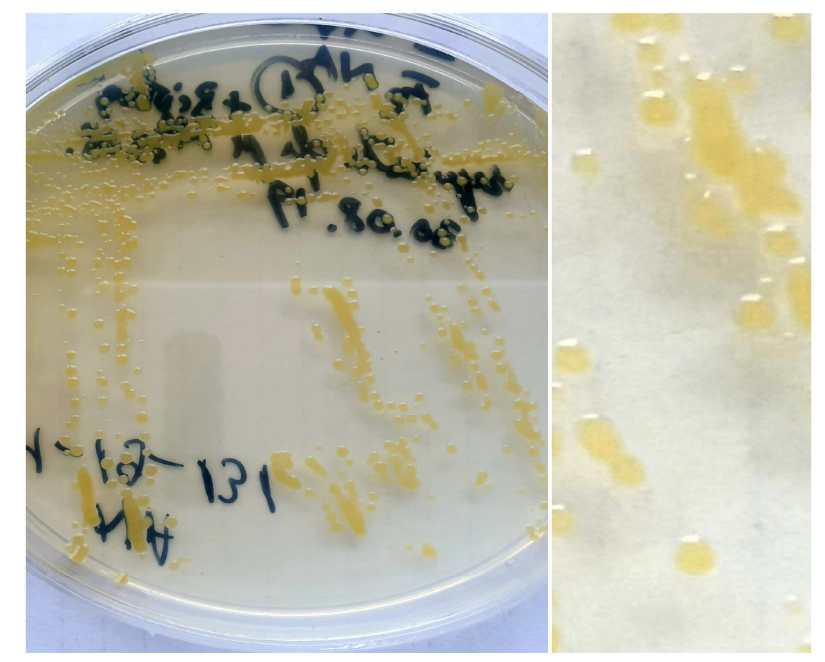

Figure 3. Bacterial colonies on non-selective media $\mathrm{NA}$

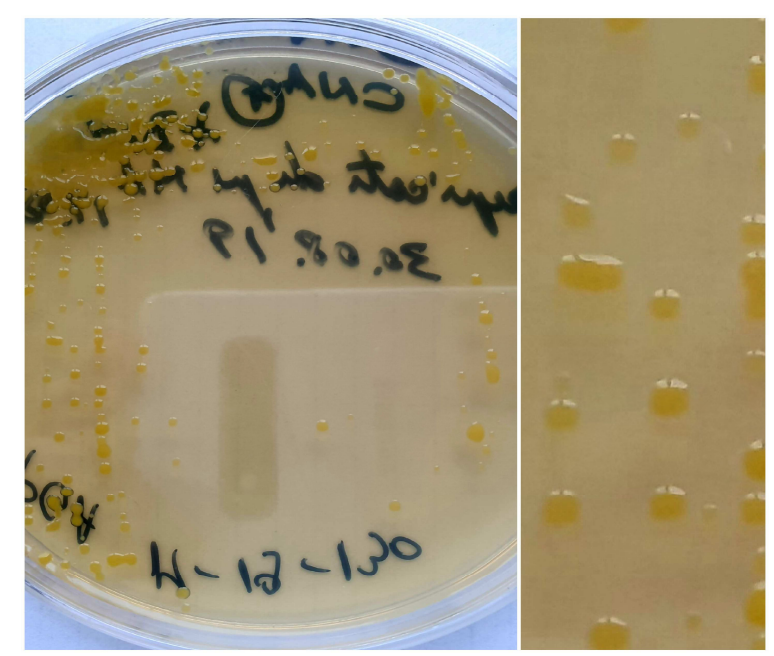

Figure 4. Bacterial colonies on non-selective media YPGA

This method was the basis for the following identification analyses, being used for both detection and identification of bacteria.

Suspected bacterial colonies grown on culture media were further analyzed in molecular biology by multiplex PCR test to confirm screening test results (figure 5).

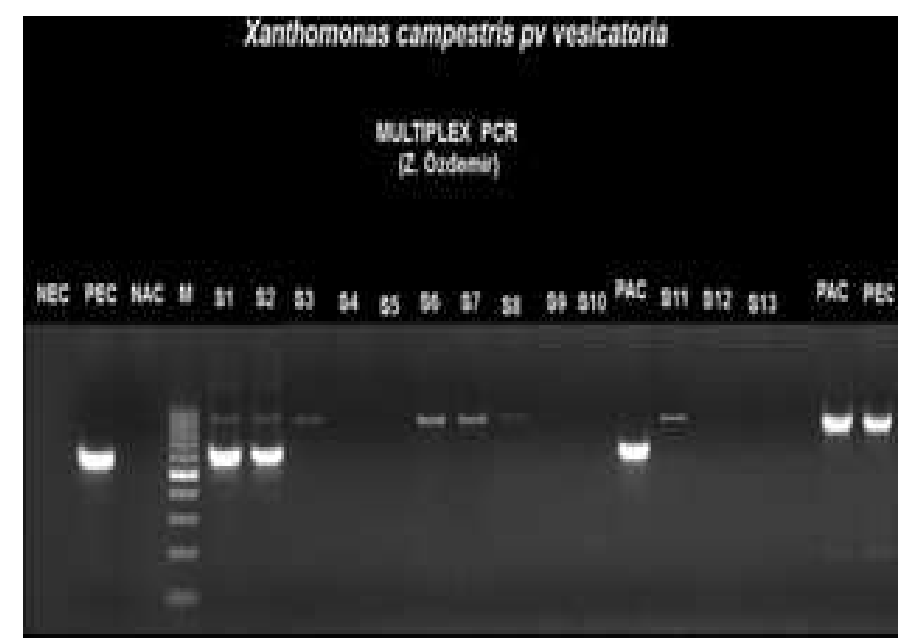

Figure 5. Multiplex PCR test result

Bacterial colonies that have a positive result from the molecular biology tests were subcultured on the BUG Agar culture medium (Biolog Universal Growth Agar) to be analyzed also regarding the use of carbon sources using the BIOLOG microorganisms identification system as Severin and Cornea mentioned in 2009 .

The BIOLOG system (OmniLog) uses 96 well microplates that contain a wide range of carbon sources and which, following inoculation with a pure culture, generate a specific pattern. The results obtained after incubation at $33^{\circ} \mathrm{C}$ for $22-48$ hours were entered in the program and were 


\section{Current Trends in Natural Sciences}

Vol. 9, Issue 17, pp. 31-37, 2020

https://doi.org/10.47068/ctns.2020.v9i17.004

Current Trends in Natural Sciences (on-line)

ISSN: 2284-953X

Current Trends in Natural Sciences (CD-Rom)

ISSN: 2284-9521

ISSN-L: 2284-9521

ISSN-L: 2284-9521

compared with the database of the identification system that contains over 2900 species of bacteria and filamentous fungi.

The results obtain at Biolog system also confirmed the previous positive results (figure 6).



Figure 6. Microplate and Biolog result generated by the system

The pathogenicity test confirming that the bacterial colonies obtained by isolation on the culture media were pathogenic and the disease was reproduced on the test plants was performed in the quarantine greenhouse (figure 7). The plants were grown at a temperature of $25^{\circ} \mathrm{C}$ and humidity of $70-80 \%$ and the samples were observed at 4 weeks.

In the greenhouse the pathogenicity test was made by inoculated with at least $10^{7} \mathrm{ufc} / \mathrm{mL}$ bacterial suspension of a pure culture at young tomato plants of susceptible cultivars Moneymaker, following the recommendations of the EPPO Protocol PM 7/110 (1) of 2013 which indicates the use of this tomato variety to establish pathogenicity of bacteria extracted from both tomato and pepper samples.

For the detection and identification of bacteria Xanthomonas campestris pv.vesicatoria were performed analyses according to the flow diagram of the OEPP working protocol PM 7/110 (1), 2013 wich allows the laboratory to identify this pathogenic phytobacteriosis on tomato and pepper.

Bacterial colonies obtained by isolation on the culture medium were pathogenic and the disease was reproduced on the test plants at the pathogenicity test.

The reisolation and identification of the bacteria, obtained from test plants that present symptoms, completed the positive pathogenicity test.

The sample was considered positive for Xanthomonas campestris pv.vesicatoria because all the tests in the detection and identification schemes were positive. 


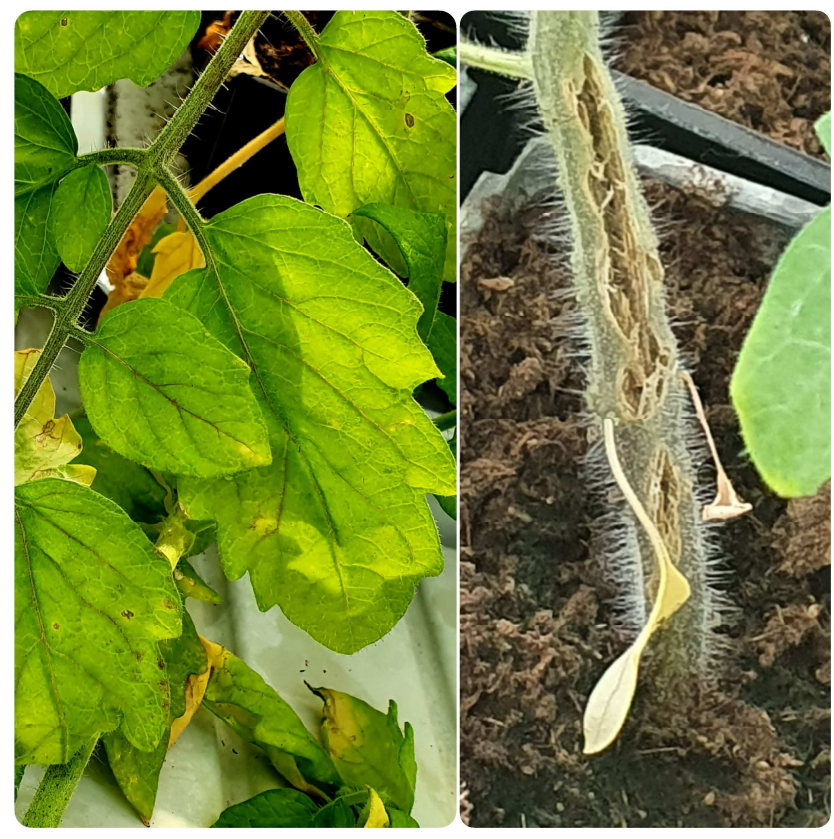

Figure 7. Pathogenicity-symptoms on leaves and stem on tomato in the greenhouse after 4 weeks

\section{CONCLUSIONS}

The main sources of infection for Xanthomonas spp. species, which cause the disease called bacterial spot of tomato and pepper, are infected seeds. Bacteria can survive on and inside the seeds and plants that grow from infected seeds, even if initially are asymptomatic, when favorable conditions for the development of phytopathogens such as heat and humidity, it begins to show symptoms of the disease.

A common but dangerous practice, which promotes the spread of Xanthomonas spp., is the use of seeds kept by farmers from contaminated crops and used as propagation material in the following years, which increases the risk of spreading this phytobacteriosis and decreases the production of quality fruits and crops.

\section{REFERENCES}

Aiello, D., Scuderi, G., Vitale, A., Firrao, G., Polizzi, G., Cirvilleri, G. (2013). A pith necrosis caused by Xanthomonas perforans on tomato plants. European Journal of Plant Pathology, 137 (1), 29-41.

Doidge, E.M. (1920). A tomato canker. Annals of Applied Biology, 7, 407-430.

Dye, D.W. (1966). Cultural and biochemical reaction of additional Xanthomonas species. New Zealand Journal of Science, 9, 913-919.

EFSA PLH Panel (European Food Safety Authority Panel on Plant Health) (2014). Scientific Opinion on the pest categorization of Xanthomonas campestris pv. vesicatoria (Doidge) Dye. EFSA Journal 12(6):3720, 1-26.

EPPO (European and Mediterranean Plant Protection Organization) (2009), EPPO Standards Diagnostics PM 7/97 (1) Indirect imunofluorescence test for plant pahogenic bacteria. EPPO Bulletin 39, 413-416.

EPPO (European and Mediterranean Plant Protection Organization) (2013), EPPO Standards Diagnostics PM 7/110 (1) Xanthomonas spp. (Xanthomonas euvesicatoria, Xanthomonas gardneri, Xanthomonas perforans, Xanthomonas vesicatoria) causing bacterial spot of tomato and sweet pepper. EPPO Bulletin 43(1), 7-20.

Jones, J.B., Lacy, G.H., Bouzar, H., Stall, R.E., Schaad, N.W. (2004). Reclassification of the xanthomonads associated with bacterial spot disease of tomato and pepper. Systematic Applied Microbiology, 27, 755-762. 


\section{Current Trends in Natural Sciences}

Vol. 9, Issue 17, pp. 31-37, 2020

https://doi.org/10.47068/ctns.2020.v9i17.004

Current Trends in Natural Sciences (on-line)

ISSN: 2284-953X

Current Trends in Natural Sciences (CD-Rom)

ISSN: 2284-9521

ISSN-L: 2284-9521

ISSN-L: 2284-9521

Official Monitor of Romania, Part I, No. 468 bis /12.VII.2007, Decision for the approval of the methodological norms for applying the Government Ordinance No. 136 / 2000 regarding the protection measures against the introduction and spread of the quarantine organisms harmful to plants or plant products in Romania.

Patel, M.K., Kulkarni, Y.S., Dhande, G.W. (1950). Bacterial spots of chillies. Indian Phytopatology, 3 (1), 95-97.

Severin, V., Iliescu, C.H. (2006). Bolile bacteriene ale plantelor [Bacterial diseases of plants] (pp. 19, 163-168). Bucureşti: Ed. Geea, Bucureşti.

Severin, V., Cornea, C.P. (2009). Ghid pentru diagnoza bolilor plantelor [Guide for the diagnosis of plant diseases] (pp 205-206). Bucureşti: Ed. Ceres, Bucureşti.

Standard ASRO- SR EN ISO/ IEC 17025 (2018). Cerințe generale pentru competența laboratoarelor de încercări şi etalonări [General requirements for the competent testing and calibration laboratory]

Šutic, G. (1957). Bakterioze crvenog patlidzana (Tomato bacteriosis). Posebna Izd. Inst. Zast. Bilja Beograd ( Spec. Edit. Inst. Plant Prot. Beograd), 6, 1-65. English summary: Review of Applied Mycology, 36, 734-735.

Vauterin, L., Hoste, B., Kersters, K., Swings, J. (1995). Reclassification of Xanthomonas. International Journal of Systematic Bacteriology, 30, 472-489. 